\title{
Hyperthermia and radiation reduce the toxic side-effects of bufadienolides for cancer therapy
}

\author{
HEBA EMAM $^{1}$, ALAA REFAAT ${ }^{2}$, PARAS JAWAID ${ }^{1}$, MATI UR REHMAN ${ }^{1}$, \\ PENG LI $^{1}$, QING-LI ZHAO ${ }^{1}$ and TAKASHI KONDO ${ }^{1}$ \\ Departments of ${ }^{1}$ Radiological Sciences and ${ }^{2}$ Cancer Cell Biology, Graduate School of Medicine \\ and Pharmaceutical Sciences, University of Toyama, Toyama 930-0194, Japan
}

Received March 8, 2016; Accepted March 30, 2017

DOI: $10.3892 / \mathrm{ol} .2017 .6256$

\begin{abstract}
Bufadienolides are constituents of the traditional Chinese medicine Chan $\mathrm{Su}$ and are found in toad venom. Cardiovascular side-effects are one of the limiting factors towards developing bufadienolides as chemotherapeutic agents. Thus, in the present study, low doses of bufalin and cinobufotalin, prominent members of the bufadienolides, were investigated for their cytotoxic activity in combination with hyperthermia (HT) or radiation (Rad) therapy. In addition, the underlying mechanism involved was investigated. A DNA fragmentation assay, viability assay and microscopic observation were primarily used to assess the effect of low doses of the two drugs in human lymphoma U937 cells. Furthermore, the effects of these drugs on the mitochondrial membrane potential (MMP) and apoptotic-associated protein activation were investigated. HT/bufadienolide- and RT/bufadienolide-treated samples significantly increased the DNA fragmentation percentile and decreased the MMP, as well as increasing the apoptotic features observed microscopically within a relatively short time ( $6 \mathrm{~h}$ ) after treatment. The two combinations affected the expression of important apoptotic markers, including caspase-3 and BH3 interacting domain death agonist. The findings of the current study confirm the additive effect of HT with this group of drugs, directing a novel therapeutic avenue for the clinical use of bufadienolides at lower doses with more restrained cardio toxic side-effects.
\end{abstract}

\section{Introduction}

Bufalin (B) and cinobufotalin (CB) are two members of the cardiotonic steroids known as the bufadienolides and

Correspondence to: Professor Takashi Kondo, Department of Radiological Sciences, Graduate School of Medicine and Pharmaceutical Sciences, University of Toyama, 2630 Sugitani, Toyama 930-0194, Japan

E-mail:kondot@med.u-toyama.ac.jp

Key words: bufalin, cinobufotalin, bufadienolides, hyperthermia, radiation, heat shock $70-\mathrm{kDa}$ protein constituents of the traditional Chinese medicine Chan Su. The drugs are also known to be found in toad venom, which is extracted from the skin secretions of giant toads, including Bufo gargarizans (1). In a previous study, we found that CB was able to significantly induce apoptotic cell death in the human lymphoma U937 cell line at concentrations $>0.5 \mu \mathrm{M}$ (2). In addition, B was demonstrated to significantly induce apoptotic cell death in various cancer cell types at concentrations $>0.1 \mu \mathrm{M}(3-6)$. The preferential killing of tumor cells by bufadienolides has made them potential candidates for chemotherapeutic research in the last 50 years; however, owing to their structural resemblance to digitalis glycosides, they also act as potent cardiotonic steroids, which increase the contractile force of the heart muscle. This effect is a result of the action of bufadienolides on the $\mathrm{Na}^{+} / \mathrm{K}^{+}$-ATPase pump, an essential membrane protein of animal cells, which results in an increase in the cytoplasmic $\mathrm{Ca}^{2+}$ concentration (1). The application of bufadienolides in cancer treatment is, therefore, restricted by their cardiotoxic side-effects.

Previous studies have revealed that hyperthermia (HT) and radiation ( $\mathrm{Rad}$ ) are able to enhance the cell killing effect of cytotoxic drugs, termed thermal- and radio-chemosensitization, either directly through affecting drug activity or indirectly through affecting the cancer cell itself (7-12). The adjuvant effect of this combination allows for the lowering of the chemotherapeutic dose required, thus lowering the unfavorable side-effects. Overall, the benefits of their concomitant use evidently overweigh the possible aforementioned disadvantages. For this reason, the scope of the present study was to investigate the possibility of lowering the chemotherapeutic dose of bufadienolides in combination with HT or Rad, while maintaining the chemotherapeutic efficacy.

\section{Materials and methods}

Drug and drug concentration. CB was purchased from Sigma-Aldrich (Merck KGgA, Darmstadt, Germany), while B was purchased from Enzo Life Sciences, Inc. (Farmingdale, NY, USA). Stock solutions were prepared using DMSO as a solvent, and further dissolved to make the desired concentrations for experimental use. The minimum toxic doses of $\mathrm{CB}$ and $\mathrm{B}$ were then determined using DNA fragmentation and cell viability assays, and were identified as 0.2 and $0.1 \mu \mathrm{M}$, 


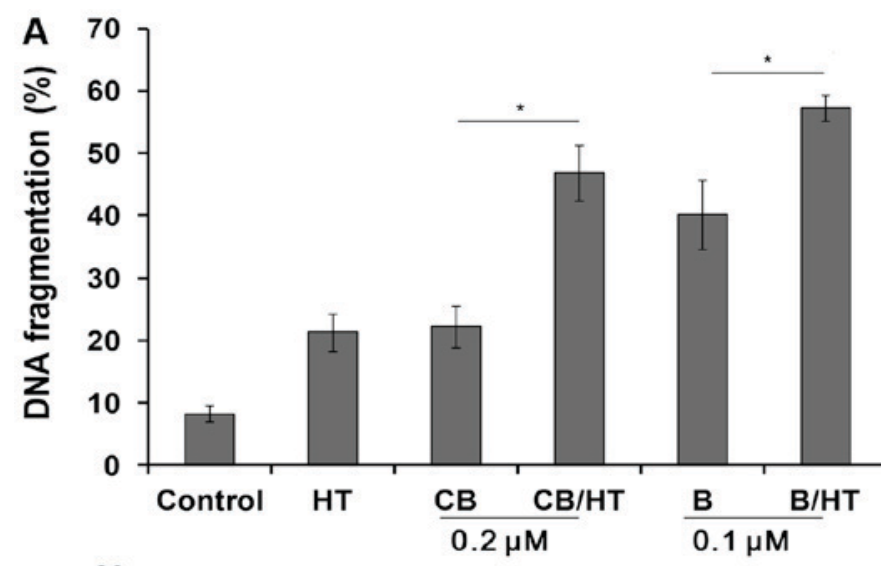

B
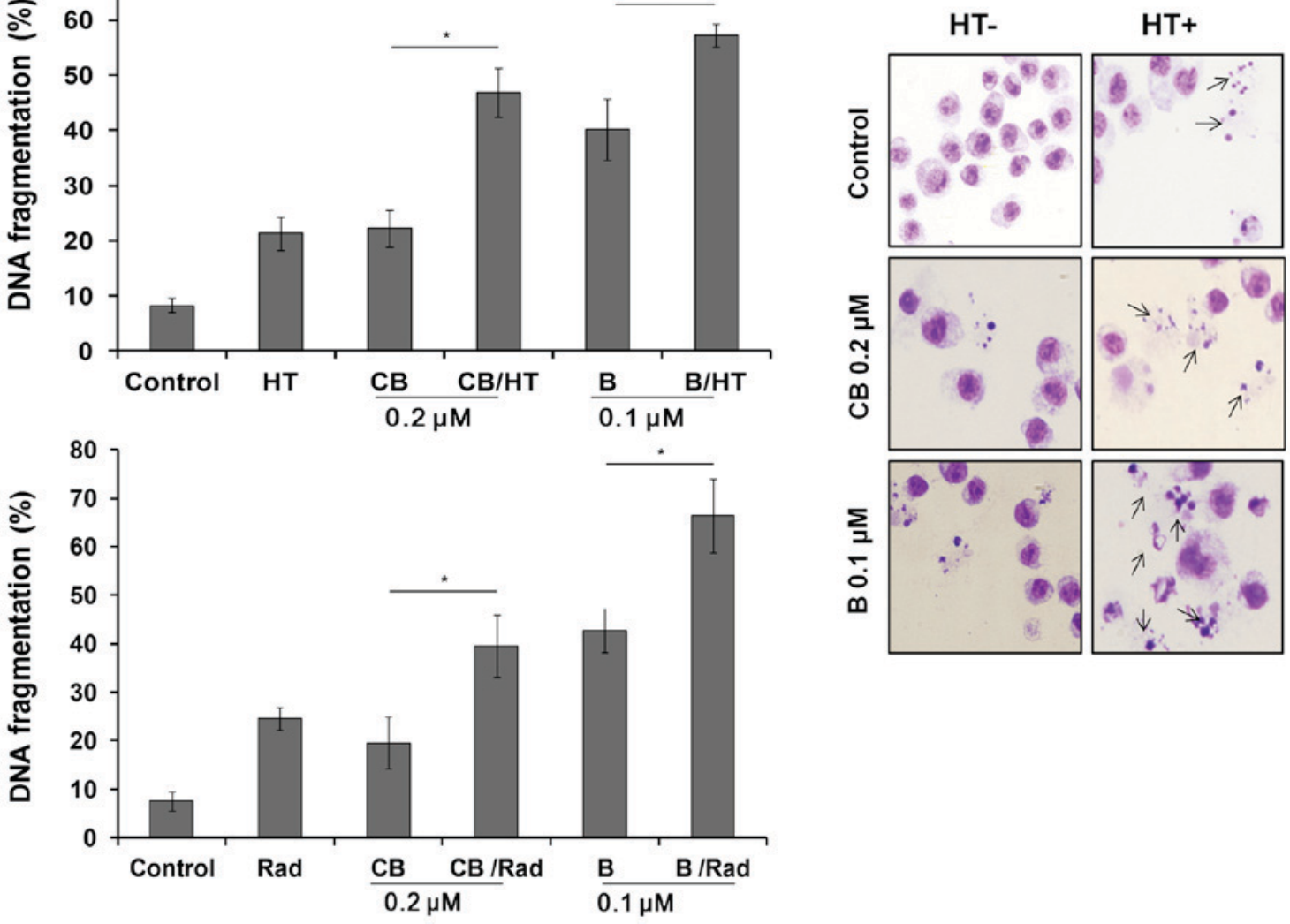

Figure 1. DNA fragmentation analysis and the assessment of morphological features of apoptosis in U937 cells. (A) DNA fragmentation analysis. (B) Giemsa staining examined under a light microscope for signs of apoptosis, indicated by arrows, at a magnification of $x 400$. Data are presented as the mean \pm standard deviation. ${ }^{*} \mathrm{P}<0.01$. B, bufalin; $\mathrm{CB}$, cinobufotalin; HT, hyperthermia; Rad, radiation.

respectively (data not shown). Accordingly, further experiments were conducted using these concentrations for 6-h incubation periods.

Cell culture. The human lymphoma U937 cell line, obtained from the Health Sciences Research Resource Bank (Japan Health Sciences Foundation, Tokyo, Japan) was maintained in RPMI-1640 medium supplemented with 10\% heat-inactivated fetal bovine serum (FBS; both Sigma-Aldrich; Merck KGaA). The cell line was maintained at $37^{\circ} \mathrm{C}$ in a humidified atmosphere with $5 \% \mathrm{CO}_{2}$. Cells were harvested when they reached $80 \%$ confluence and subcultures of $1 \times 10^{6}$ cells $/ \mathrm{ml}$ were used in all assays.

Heat stress exposure. HT is known to cause cell membrane damage and impairment to the ion transport mechanisms (7). Thus, treating the cells with $\mathrm{HT}$ prior to $\mathrm{B}$ and $\mathrm{CB}$ administration diminishes the cytotoxic activity of the drugs that principally target the $\mathrm{Na}^{+} / \mathrm{K}^{+}$pump. The drugs $(0.2 \mu \mathrm{M} \mathrm{CB}$ and $0.1 \mu \mathrm{M} \mathrm{B})$ were therefore administered for $1 \mathrm{~h}$ prior to HT treatment. Cells were transferred into test tubes and placed in a hot water bath at $44^{\circ} \mathrm{C}$ for $20 \mathrm{~min}$. Subsequently, the cells were transferred into plates and incubated for $6 \mathrm{~h}$ at $37^{\circ} \mathrm{C}$, prior to the required assay.

$X$-irradiation. U937 cells $\left(1 \times 10^{6}\right.$ cells $\left./ \mathrm{ml}\right)$ were treated with $\mathrm{B}$ and $\mathrm{CB}$ in a $6-\mathrm{cm}$ culture dish for $1 \mathrm{~h}$ at room temperature prior to Rad. X-irradiation was performed at room temperature using X-ray apparatus (MBR-1520R-3; Hitachi, Ltd.,
Tokyo, Japan) operating at $150 \mathrm{kV}$ and $20 \mathrm{~mA}$, at a dose rate of $5 \mathrm{~Gy} / \mathrm{min}, 10 \mathrm{~Gy}$ total as determined using Fricke dosimetry. Cells were subsequently incubated for $6 \mathrm{~h}$ at $37^{\circ} \mathrm{C}$ with $5 \% \mathrm{CO}_{2}$ for further assessment.

Assessment of apoptosis. Morphological examination was performed using Giemsa staining under a light microscope (magnification, $\mathrm{x} 400$ ), and a quantitative assay of DNA fragmentation was performed according to the modified Sellins and Cohen method $(13,14)$.

Assessment of cell viability. Cell viability was evaluated by WST-1 cell viability assay using a WST-1 Cell Counting kit (Dojindo Molecular Technologies Inc., Kumamoto, Japan) according to the manufacturer's protocol. Briefly, cell suspensions were subjected to drug (CB or B) treatment, HT or Rad, then equal volumes of the cell suspension were seeded into 96-well plate followed by a further incubation period for $6 \mathrm{~h}$ at $37^{\circ} \mathrm{C}$. Subsequently, cells were subjected to the WST-1 assay. The absorbance was measured at $450 \mathrm{~nm}$ using a microplate reader.

Assessment of mitochondrial membrane potential (MMP). To measure the changes in the MMP, U937 cells were harvested by centrifugation at $350 \mathrm{x} \mathrm{g}$ at $4^{\circ} \mathrm{C}$ for 4 mins and stained with $10 \mathrm{nM}$ tetramethylrhodamine methyl ester (TMRM; Molecular Probes; Thermo Fisher Scientific, Inc., Waltham, MA, USA) for 15 min at $37^{\circ} \mathrm{C}$ in PBS containing $1 \%$ FBS. 

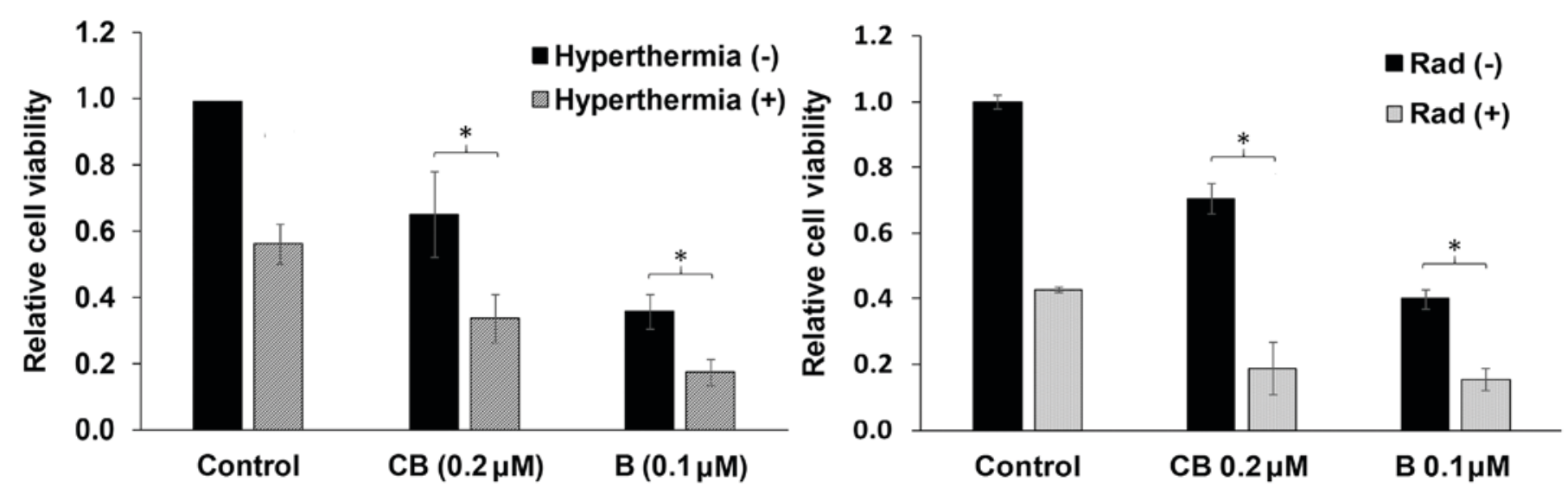

Figure 2. Assessment of the cell viability in U937 cells. Time-dependent effect of $0.2 \mu \mathrm{M}$ CB and $0.1 \mu \mathrm{MB}$ on the growth of U937 cells relative to the untreated control group was assessed using WST-1 reagent. ${ }^{*} \mathrm{P}<0.01$. Data are presented as the mean \pm standard deviation. B, bufalin; $\mathrm{CB}$, cinobufotalin; Rad, radiation.

The fluorescence of TMRM was then analyzed using flow cytometry (excitation wavelength, $488 \mathrm{~nm}$; emission wavelength, $575 \mathrm{~nm})(15)$.

Western blot analysis of proteins. Western blot analysis was performed as described previously (2). Cells were collected and washed with cold PBS, then lysed using lysis buffer for 20 min at $4^{\circ} \mathrm{C}(1 \mathrm{M}$ Tris- $\mathrm{HCl}, 5 \mathrm{M} \mathrm{NaCl}, 1 \%$ Nonidet P-40 (v/v), $1 \%$ sodium deoxycholate, $0.05 \%$ SDS, $1 \mathrm{mM}$ phenylmethylsulfonyl fluoride). Following brief sonication, the lysates were centrifuged at $13,362 \times \mathrm{g}$ for $10 \mathrm{~min}$ at $4^{\circ} \mathrm{C}$ and the protein content in the supernatant was measured using a Bio-Rad protein system (Bio-Rad Laboratories, Inc., Hercules, CA, USA). Total protein $(30 \mu \mathrm{g})$ was heated at $96^{\circ} \mathrm{C}$ for $5 \mathrm{~min}$ following mixing with $5 \mu 1$ of SDS-loading buffer. Samples were then subjected to $12 \%$ SDS-PAGE (Daiichi Pure Chemicals Co., Ltd., Tokyo, Japan) and transferred to nitrocellulose membranes (GE Healthcare Life Sciences, Chalfont, UK). Membranes were then blocked using $1 \mathrm{X}$ Tris-buffered saline-Tween 20 with $5 \% \mathrm{w} / \mathrm{v}$ non-fat dry milk for $1 \mathrm{~h}$ at room temperature. Western blot analysis was performed using anti-BH3 interacting domain death agonist (Bid,), anti-caspase-3 and anti-heat shock 70-kDa protein (HSP-70; 2002S, 9661S and 4872S, respectively; Cell Signaling Technology, Inc., Danvers, MA, USA) polyclonal antibodies, and anti- $\beta$-actin monoclonal antibody (A2228, Sigma-Aldrich; Merck KGgA). The membranes and the primary antibodies (all at 1:1,000 dilution) were incubated overnight with gentle agitation at $4^{\circ} \mathrm{C}$. Following their incubation with horseradish peroxidase-conjugated anti-rabbit and anti-mouse immunoglobulin G secondary antibodies for $1 \mathrm{~h}$ at room temperature, band signals were visualized on X-ray film using a chemiluminescence EspspCL system (NA934 and NA931, respectively; GE Healthcare Life Sciences, Chalfont, UK) (15).

Statistical analysis. The statistical analysis was performed using JMP software (version 10; SAS Institute, Inc., Cary, NC, USA). Data are presented as the mean \pm standard deviation. Statistical significance was evaluated using one-way analysis of variance followed by the Bonferroni post hoc test. All experiments were performed in triplicate. $\mathrm{P}<0.01$ was considered to indicate a statistically significant difference.

\section{Results}

Effect of combining HT or Rad on the cytotoxic activity of $B$ and $C B$. Based on our previous studies, the minimum toxic doses for B and CB in U937 cells were identified as 0.01 and $0.2 \mu \mathrm{M}$, respectively $(2,5,6)$. Upon further analysis, administration of $\mathrm{B}(0.1 \mu \mathrm{M})$ and $\mathrm{CB}(0.2 \mu \mathrm{M})$ in combination with HT ( $44^{\circ} \mathrm{C}$ for $\left.20 \mathrm{~min}\right)$ or Rad $(10 \mathrm{~Gy})$ was demonstrated to significantly increase the DNA fragmentation compared with single-drug treatment groups $(\mathrm{P}<0.01$; Fig. 1A). Treated cells were then examined using Giemsa staining under a light microscope. Untreated cells exhibited intact nuclear structure, whereas B and CB in combination with HT-treated cells showed typical apoptotic morphological changes, as indicated by chromosomal condensation and nuclear fragmentation (Fig. 1B).

Decrease in cell viability. U937 cells were treated as aforementioned, followed by use of the WST-1 cell viability assay. In coherence with the previous assays, B/HT- and CB/HT-treated cells showed a significant decrease in cell viability, reaching $40.0 \pm 4.0$ and $35.0 \pm 3.0 \%$, respectively, following $6 \mathrm{~h}$ of incubation (Fig. 2). Similarly, B/Rad- and CB/Rad-treated cells

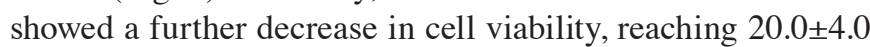
and $15.0 \pm 3.0 \%$, respectively, following $6 \mathrm{~h}$ of incubation (Fig. 2).

Induction of MMP. To assess the effect of these combinations on the MMP of U937 cells, treated cells were assessed for MMP decline using TMRM staining. The results revealed significant reductions in MMP in the combination-treatment groups compared with treatment with the drugs alone, as shown in Fig. 3.

Effect on apoptosis-associated protein expression. Caspases serve an important role in the apoptotic signaling pathway and are considered as the main executioners of cell death (16). To examine the involvement of the caspases in the effect of HT or Rad on the two drugs, western blot analysis was performed using caspase-3 antibody following $6 \mathrm{~h}$ of treatment of U937 cells using the treatment combinations. Given that the activation of a specific caspase results 

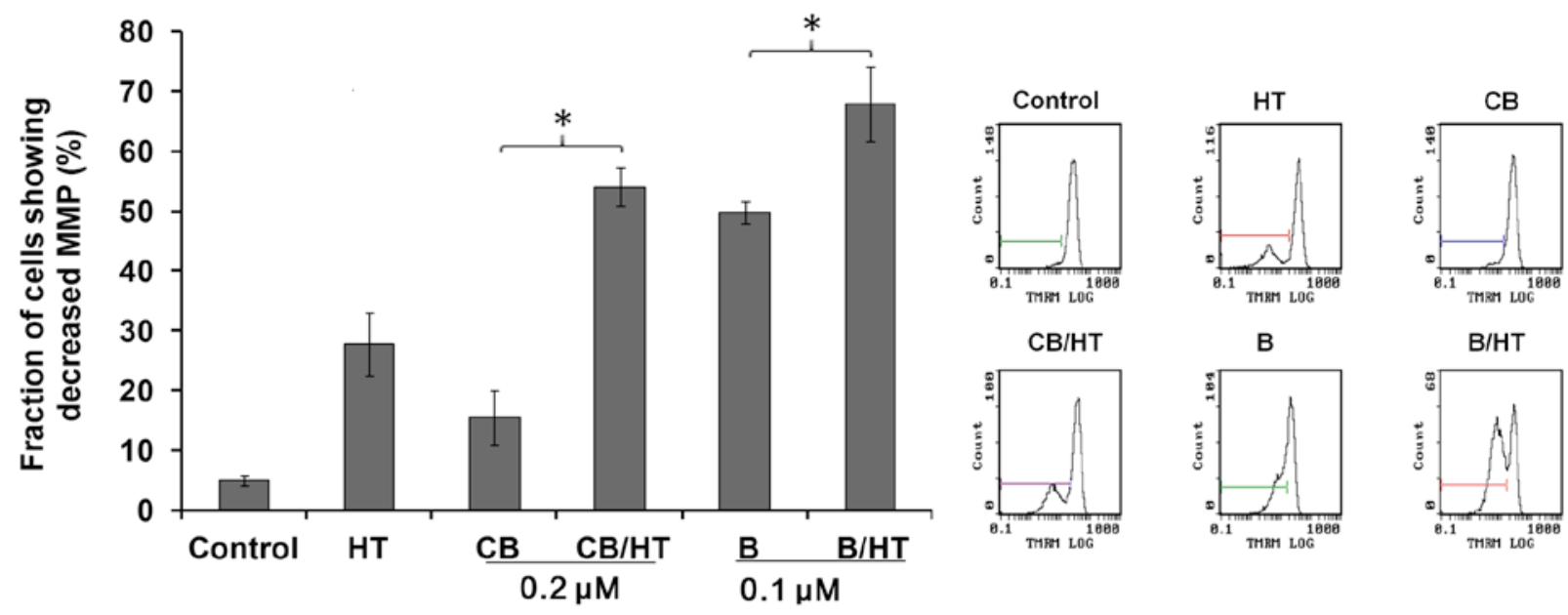

$\mathrm{CB} / \mathrm{HT}$

B
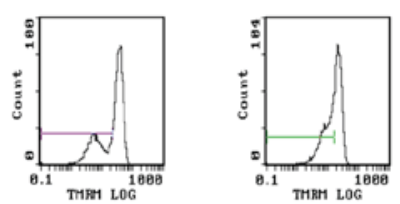

B/HT
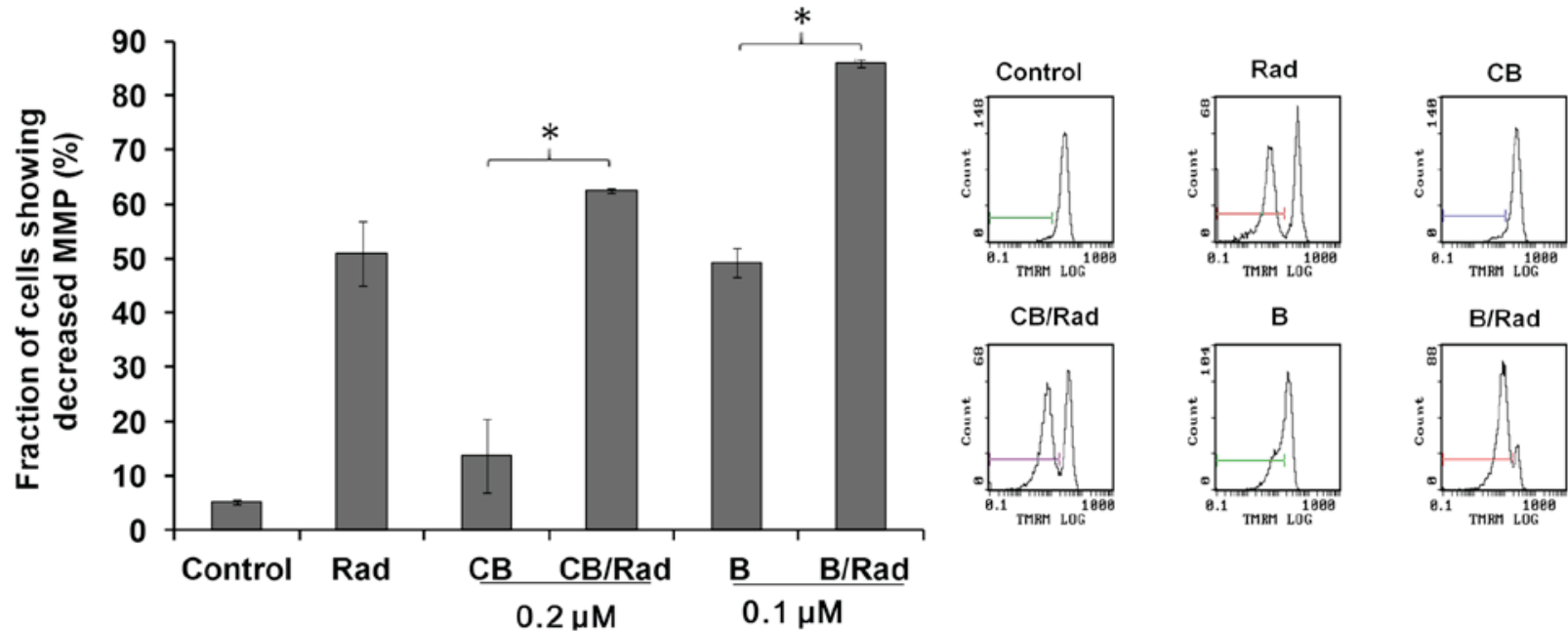

Figure 3. Assessment of the MMP using TMRM staining. U937 cells treated with $0.2 \mu \mathrm{M} \mathrm{CB}$ and $0.1 \mu \mathrm{M}$ B for $1 \mathrm{~h}$ followed by $\mathrm{HT} 44^{\circ} \mathrm{C}$ for 20 min or $\mathrm{X}$-irradiation $(10 \mathrm{~Gy})$. Cells were then incubated for $6 \mathrm{~h}$, followed by TMRM staining and flow cytometry analysis. ${ }^{*} \mathrm{P}<0.01$. Data are presented as the mean \pm standard deviation. B, bufalin; CB, cinobufotalin; HT, hyperthermia; Rad, radiation; MMP, mitochondrial membrane potential; TMRM, tetramethylrhodamine methyl ester.

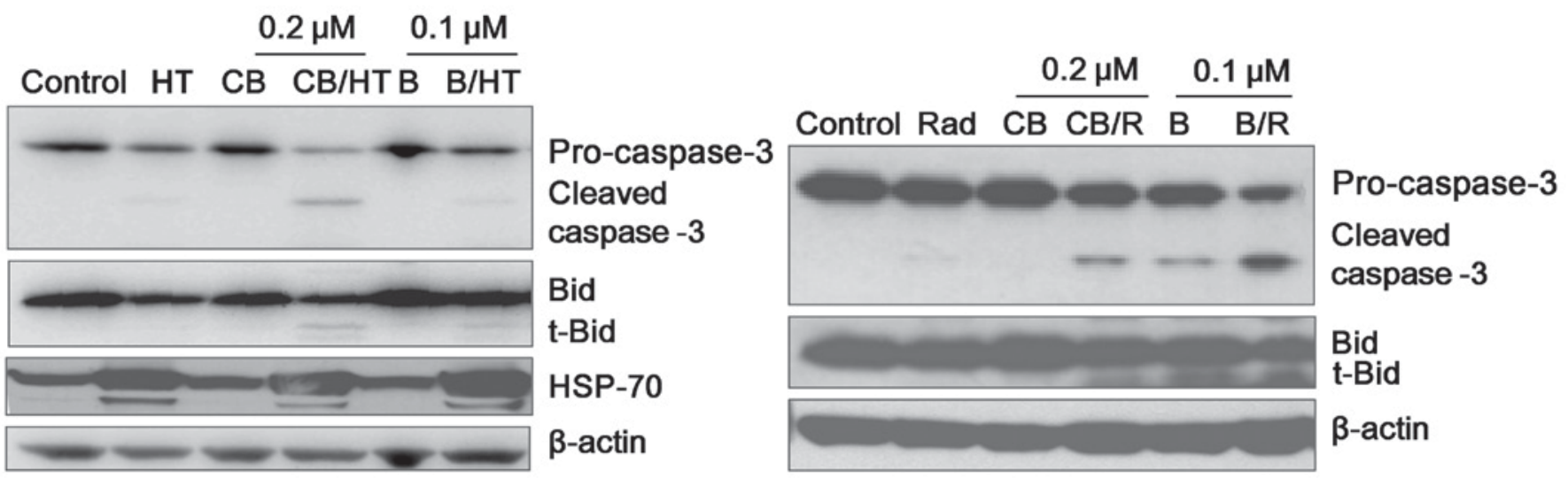

Figure 4. Assessment of apoptotic protein expression in U937 cells using western blot analysis. Changes in caspase-3, Hsp-70 and Bid protein expression following treatment with a combination of either drug with HT or Rad and incubation of the treated cells for $6 \mathrm{~h}$. B, bufalin; CB, cinobufotalin; HT, hyperthermia; R, radiation; Bid, BH3 interacting domain death agonist; t, truncated; HSP-70, heat shock 70-kDa protein.

in the reduction of its pro-enzyme form, it was demonstrated that the protein levels of procaspase-3 were markedly downregulated in the HT- or Rad-treated groups (Fig. 4). Simultaneously, the cleaved form of caspase-3 was also markedly detectable in the groups treated in combination with HT or Rad. Expression of activated pro-apoptotic proteins, including Bid, were also demonstrated to be markedly decreased with regard to cytosolic levels, as shown in Fig. 4. However, HSP70 expression was upregulated in the HT-treated groups. 


\section{Discussion}

Cardiac glycosides (CG) belong to the most commonly used group of drugs in medicine. The two main subgroups of $\mathrm{CG}$ are the cardenolides, where ouabin and its derivative digoxin are the most typical examples, and the bufadienolides, which the present study was focused upon. There are $\sim 250$ substances in the bufadienolide group, including B and CB (17). The bufadienolides have been previously investigated in several studies for their cytotoxic activity, as well as the underlying signaling pathway involved (3-6). Bufadienolides act primarily through inhibiting the transport enzyme $\mathrm{Na}^{+} / \mathrm{K}^{+}$-adenosine triphosphatase (18), thus acting as their signal transducer. Conversely, despite the cytotoxic nature of bufadienolides, a previous study reported their use in cardiovascular and kidney diseases (19). Introducing the bufadienolides as chemotherapeutic agents also depends on the extent of their cardiovascular side-effects. However, their cell type specificity towards cancer cells and the use of specific bufadienolides at low doses and for long periods without severe side-effects have been reported $(20,21)$. Thus, in the present study, the use of B and CB was investigated at the lowest cytotoxic dose in combination with HT or $\mathrm{Rad}$ in order to attain a significant cytotoxicity with limited possible side-effects.

HT efficacy is not sufficient to replace any of the therapeutic modalities when used alone, yet it has shown significant results in enhancing the cell killing effect of other cytotoxic drugs. HT induces several changes in the cellular physiology, including at the level of the cell membrane of the cancer cell and on a nucleic acid level (7). Generally, HT cannot cause severe damage by itself, but instead, independently hinders the repair of cell damage $(22,23)$. Furthermore, HT affects the fluidity and stability of cellular membranes, and hinders the function of the transmembrane transport proteins and cell surface receptors (24-28). In addition, X-irradiation is known to induce apoptosis by acting directly on the plasma membrane and nuclear DNA, or both (14). Simultaneously, mitochondrial-dependent generation of reactive oxygen species serves an essential role in $\mathrm{G}_{2} / \mathrm{M}$ arrest and $\mathrm{X}$-irradiation-induced apoptosis $(29,30)$. Accordingly, the present study reported promising results when $\mathrm{B}$ and $\mathrm{CB}$ were administered $1 \mathrm{~h}$ prior to HT or Rad treatment avoiding its destructive effect on the cell membrane, which is the primary target of $\mathrm{B}$ and $\mathrm{CB}$.

In all the assays in the current study, B was identified to be generally more cytotoxic when compared with $\mathrm{CB}$, and HT significantly enhanced the cytotoxic effect of low doses of the two drugs. Notably, HT was able to potentiate the cytotoxic activity of $\mathrm{CB}$ to be almost equal to that of $\mathrm{B}$ alone. The apoptotic nature of the drugs appeared to be unhindered yet augmented. Firstly, using Giemsa staining, the presence of apoptotic-like bodies in all treatment groups was demonstrated and was more evident in the $\mathrm{CB} / \mathrm{HT}$ and $\mathrm{B} / \mathrm{HT}$ combinations compared with the groups with drug treatment alone. To assess the viability of the cells, a WST-1 cell viability assay was used. The results demonstrated that $\sim 50 \%$ of the cells died within $6 \mathrm{~h}$ in the $\mathrm{CB} / \mathrm{HT}$ and B/HT combination groups vs. 20-30\% of cells when the drugs were used alone. Additionally, the DNA fragmentation assay revealed a significant increase in the DNA fragments in the combination groups. Furthermore, the effects of the combinations were greater when assessing the MMP, since there was doubling in the MMP percentile loss in the two drugs. MMP is the preliminary step towards the initiation of programmed cell death $(31,32)$. This eventually leads to the activation of caspase-3, followed by DNA fragmentation and cell death $(33,34)$. HT and Rad enhanced the expression of caspase- 3 and Bid proteins when combined with the drugs. However, the upregulation of HSP70, acknowledged as an anti-apoptotic protein, remains a question to be assessed. Nevertheless, few previous studies have demonstrated the apoptotic nature of the HSP70 protein. This could stand as an explanation for the lack of a synergistic effect of this combination (35).

In conclusion, HT and Rad, in combinations with low doses of B and CB appear to enhance the apoptotic cell death of U937 cells through the intrinsic apoptotic signaling pathway. Notably, when combined with $\mathrm{CB}$, chemotherapeutic effects were demonstrated equivalent to the relatively more toxic $\mathrm{B}$ used alone. The present study has provided a direction for the introduction of $\mathrm{B}$ and $\mathrm{CB}$ into the chemotherapeutic field, ensuring similar efficacy while reducing the anticipated side-effects of high doses.

\section{References}

1. XuY, Liu X, Schwarz S, Hu L, Guo D, Gu Q and Schwarz W: Inhibitory efficacy of bufadienolides on $\mathrm{Na}^{+}, \mathrm{K}^{+}$-pump activity versus cell proliferation. Biochem Biophys Rep 6: 158-164, 2016.

2. Emam H, Zhao QL, Furusawa Y, Refaat A, Ahmed K, Kadowaki $\mathrm{M}$ and Kondo T: Apoptotic cell death by the novel natural compound, cinobufotalin. Chem Biol Interact 199: 154-160, 2012.

3. Yin PH, Liu X, Qiu YY, Cai JF, Qin JM, Zhu HR and Li Q: Anti-tumor activity and apoptosis-regulation mechanisms of bufalin in various cancers: New hope for cancer patients. Asian Pac J Cancer Prev 13: 5339-5343, 2012.

4. Takai N, Kira N, Ishii T, Yoshida T, Nishida M, Nishida Y, Nasu K and Narahara H: Bufalin, a traditional oriental medicine, induces apoptosis in human cancer cells. Asian Pac J Cancer Prev 13: 399-402, 2012.

5. Watabe M, Ito K, Masuda Y, Nakajo S and Nakaya K: Activation of AP-1 is required for bufalin-induced apoptosis in human leukemia U937 cells. Oncogene 16: 779-787, 1998.

6. Watabe M, Masuda Y, Nakajo S, Yoshida T, Kuroiwa Y and Nakaya K: The cooperative interaction of two different signaling pathways in response to bufalin induces apoptosis in human leukemia U937 cells. J Biol Chem 271: 14067-14072, 1996.

7. Hildebrandt B, Wust P, Ahlers O, Dieing A, Sreenivasa G, Kerner T, Felix R and Riess H: The cellular and molecular basis of hyperthermia. Crit Rev Oncol Hematol 43: 33-56, 2002.

8. Engin K, Tupchong L, Moylan DJ, Alexander GA, Waterman FM, Komarnicky L, Nerlinger RE and Leeper DB: Radomized trial of one versus two adjuvant hyperthermia treatments per week in patients with superficial tumors. Int J Hyperthermia 9: 327-340, 1993.

9. Urano M, Kuroda M and Nishimura Y: For the clinical application of themochemotherapy given at mild temperatures. Int $\mathrm{J}$ Hyperthermia 15: 79-107, 1999.

10. Falk MH and Issels RD: Hyperthermia in oncology. Int J Hyperthermia 17: 1-18, 2001.

11. Dewey WC, Thrall D and Gilette EL: Hyperthermia and radiation-a selective thermal effect on chronically hypoxic tumor cells in vivo. Int J Radiat Oncol Biol Phys 2: 99-103, 1977.

12. Dewey WC, Hopwood LE, Sapareto SA and Gerweck LE: Cellular responses to combinations of hyperthermia and radiation. Radiology 123: 463-474, 1977.

13. Sellins KS and Cohen JJ: Gene induction by gamma-irradiation leads to DNA fragmentation in lymphocytes. J Immunol 139: 3199-3206, 1987.

14. Hopcia KL, McCarey YL, Sylvester FC and Held KD: Radiationinduced apoptosis in HL60 cells: Oxygen effect, relationship between apoptosis and loss of clonogenicity, and dependence of time to apoptosis on radiation dose. Radiat Res 145: 315-323, 1996. 
15. Zhao QL, Fujiwara Y and Kondo T: Mechanism of cell death induction by nitroxide and hyperthermia. Free Radic Biol Med 40: 1131-1143, 2006.

16. Utz PJ, Anderson P: Life and death decisions: Regulation of apoptosis by proteolysis of signaling molecules. Cell Death Differ 7: 589-602, 2000.

17. Krenn L and Kopp B: Bufadienolides from animal and plant sources. Phytochemistry 48: 1-29, 1998.

18. Schatzmann HJ: The role of $\mathrm{Na}^{+}$and $\mathrm{K}^{+}$in the ouabain-inhibition of the $\mathrm{Na}^{+} \mathrm{K}^{+}$-activated membrane adenosine triphosphatase. Biochim Biophys Acta 94: 89-96, 1965.

19. Puschett JB, Agunanne $E$ and Uddin MN: Emerging role of the bufadienolides in cardiovascular and kidney diseases. Am J Kidney Dis 56: 359-370, 2010.

20. Jing Y, Ohizumi H, Kawazoe N, Hashimoto S, Masuda Y, Nakajo S, Yoshida T, Kuroiwa Y and Nakaya K: Selective inhibitory effect of bufalin on growth of human tumor cells in vitro: Association with the induction of apoptosis in leukemia HL-60 cells. Jpn J Cancer Res 85: 645-651, 1994.

21. Panesar NS: Bufalin and unidentified substance(s) in traditional Chinese medicine cross-react in commercial digoxin assay. Clin Chem 38: 2155-20156, 1992.

22. Dahm-Daphi J, Brammer I and Dikomey E: Heat effects on the repair of DNA double-strand breaks in CHO cells. Int J Radiat Biol 72: 171-179, 1997.

23. Dikomey E and Franske J: Effect of heat on induction and repair of DNA strand breaks in X-irradiated CHO cells. Int J Radiat Biol 61: 221-233, 1992.

24. Calderwood SK and Hahn GM: Thermal sensitivity and resistance of insulin-receptor binding. Biochim Biophys Acta 756: $1-8,1983$.

25. Stevenson MA, Minton KW and Hahn GM: Survival and concanavalin- A-induced capping in $\mathrm{CHO}$ fibroblasts after exposure to hyperthermia, ethanol, and X irradiation. Radiat Res 86 : 467-478, 1981

26. Coss RA and Linnemanns WA: The effects of hyperthermia on the cytoskeleton: A review. Int J Hyperthermia 12: 173-196, 1996.
27. Konings AW and Ruifrok AC: Role of membrane lipids and membrane fluidity in thermosensitivity and thermotolerance of mammalian cells. Radiat Res 102: 86-98, 1985.

28. Majda JA, Gerner EW, Vanlandingham B, Gehlsen KR and Cress AE: Heat shock-induced shedding of cell surface integrins in A549 human lung tumor cells in culture. Exp Cell Res 210: 46-51, 1994.

29. Miyata H, Doki Y, Yamamoto H, Kishi K, Takemoto H, Fujiwara Y, Yasuda T, Yano M, Inoue M, Shiozaki H, et al: Overexpression of CDC25B overrides radiation-induced G2-M arrest and results in increased apoptosis in esophageal cancer cells. Cancer Res 61: 3188-3193, 2001

30. Corbiere C, Liagre B, Terro F and Beneytout JL: Induction of antiproliferative effect by diosgenin through activation of $\mathrm{p} 53$, release of apoptosis-inducing factor (AIF) and modulation of caspase-3 activity in different human cancer cells. Cell Res 14: 188-196, 2004

31. Gottlieb E, Armour SM, Harris MH and Thompson CB Mitochondrial membrane potential regulates matrix configuration and cytochrome $\mathrm{c}$ release during apoptosis. Cell Death Differ 10: 709-717, 2003.

32. Gottlieb RA: Mitochondria: Execution central. FEBS Lett 482: $6-12,2000$

33. Zamzami N, Marchetti P, Castedo M, Decaudin D, Macho A, Hirsch T, Susin SA, Petit PX, Mignotte B and Kroemer G: Sequential reduction of mitochondrial transmembrane potential and generation of reactive oxygen species in early programmed cell death. J Exp Med 182: 367-377, 1995.

34. Liu X, Kim CN, Yang J, Jemmerson R and Wang X: Induction of apoptotic program in cell-free extract: Requirements for dATP and cytochrome C. Cell 86: 147-157, 1996.

35. Ran R, Lu A, Zhang L, Tang Y, Zhu H, Xu H, Feng Y, Han C, Zhou G, Rigby AC and Sharp FR: Hsp70 promotes TNF-mediated apoptosis by binding IKK gamma and impairing NF-kappa B survival signaling. Genes Dev 18: 1466-1481, 2004. 